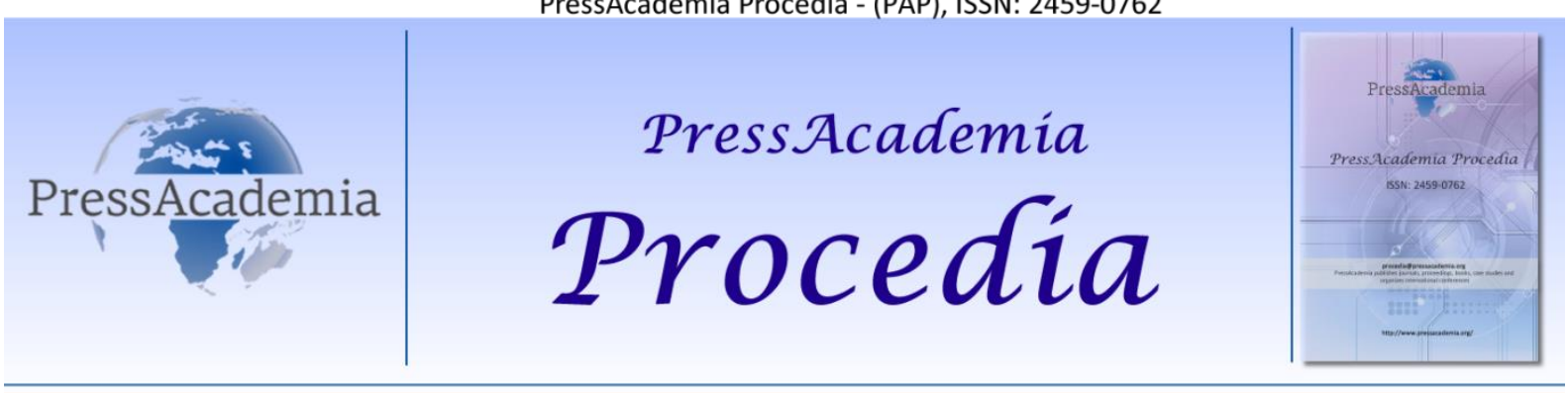

2nd World Conference on Technology, Innovation and Entrepreneurship

May 12-14, 2017, Istanbul, Turkey. Edited by Sefer Şener

\title{
AN INTEGRATED SURVEY IN AFFILIATE MARKETING NETWORK
}

\section{DOI: 10.17261/Pressacademia.2017.604}

PAP-WCTIE-V.5-2017(42)-p.299-309

\section{Ali Norouzi}

Department of Business Management, Istanbul Aydin University, Florya, Istanbul, Turkey. norouzi@ieee.org

\begin{abstract}
As the Internet plays more colorful role in our everyday lives, the consumer's shopping habits is changing toward increase in share of online purchase. Along with expansion of the Internet in people's everyday life the recent years have been featured with growth of online marketing among businesses. Firms have come to understanding that online marketing is a vital element for increasing brand awareness and grab attention of the modern consumers. Moreover, there has been a continuous increase in engagement of the consumer in social media and blogs, which makes them a key marketing channel for the businesses. Businesses currently have to admit the necessity of joining online marketing as a measure to improve their brand awareness and communicate with the target customers. Affiliate marketing functions based on marketing channel and brings less risk comparing with other online marketing channels. As an almost novel phenomenon, online marketing has experiences a continuous growth over the recent years. The present article examines affiliate marketing network, which is an online marketing channel that gives businesses the opportunity to achieve more visibility with relatively low costs. Many popular media including blogs, voucher code sites, and price comparison sites cooperate using affiliate marketing model. Different online marketing challenges are first introduced to give a theoretical background of online marketing in general. Afterward, more detailed analyses of affiliate marketing, as an online marketing channel and the main area of focus of the study is given. Affiliate marketing and all its features from theoretical aspect are discussed in this article, also commissioner and marketing plans in practice, the requirements, and the environment are discussed.
\end{abstract}

Keywords: Affiliate marketing network, affiliate program, online advertising,

\section{INTRODUCTION}

Along with fast growth of the Internet, many held that expansion of the Internet would result in disintermediation, which means elimination of intermediaries in the value chain between manufacturers and end costumers. Jacobs argued that following development of new communication ways in the new economy, distribution channel was reduces from two/three intermediaries to zero or one intermediary, which means more cost savings and customization.

At any rate, beside the fact that the Internet actually can decrease the number of intermediaries in some fields, companies still have the chance to use their expertise in adjusting their activities so that they could remain competitive at the market.

Companies were very fast to spot the marketing capacities of the Internet after introduction of the World Wide Web. By using advantages of the new technologies, companies can improve their competitive features, while the technologies bring the threat of new start-up companies that in some cases are completely virtual. Companies need to adjust their business with the trends of changes or otherwise face losing their markets.

Online marketing is featured with many divergent marketing channels that will be discussed in part 2 in short. The article is mainly focused on affiliate marketing as one of safer online marketing channels. Affiliate marketing and all its features from theoretical aspect are discussed in part 3, followed by part 4 where commissioner and marketing plans in practice, the requirements, and the environment are discussed. 


\section{ONLINE ADVERTISING}

Online advertising is far more than placing a website on the Internet even if it is designed for promotional purposes. On the contrary, advertising is a mean to attract the potential customers to that website -i.e. traffic acquisition.

From the content providers' viewpoint, online advertising is an important source of income. According to the resultoriented compensation methods, affiliate marketing is a specific way of selling advertising space. To find out when it is beneficial, advantages and disadvantages of other options available for content providers must be examined.

are several definitions for the term Internet advertising. There has been an ongoing debate on whether to consider the Interne as another form of traditional advertising or its nature is more of direct marketing.

Companies, regardless of their industry, can be divided based on their role in business transactions. Zeff highlighted three parties that participate in online advertising:

- Sellers

- $\quad$ Buyers

- Infrastructure (Zeff, 1999; 18-21)

\subsection{Sellers}

Sellers are in charge of providing content that produce websites with advertising space to sell. Many of the modern sellers are media companies. Since inventory of the content providers is not easy to sell, they were quick in developing ad networks. The networks provide experienced sales force and the advertisers find them easier to deal with.

\subsection{Buyers}

Companies with products or services to promote are the buyers. Usually, they are represented by agencies that handle their advertising campaigns.

\subsection{Infrastructure}

Companies that run services of evaluating and auditing campaigns, targeting, and personalization companies, ad management software developers, and suppliers of technological infrastructure.

\section{AFFILIATE MARKETING}

Affiliate marketing is an economic way comparing with other online advertising forms as it cuts the administrative costs of buying advertising. When the program is well managed, it enables advertising to a great extent of website which is not acquirable otherwise.

The process of affiliate marketing is explained at first and then the parties engaged in the process and their role are discussed. A detailed analyses of the parties are provided along with an introduction to advertising methods and the commission payment models. Risks of affiliate marketing and the performing affiliate programs are also introduced.

The concept of affiliate marketing is designed based on reward in return for performance and here performance is a sale, registration for a web services, signing up for e-mail marketing, request for contact or any other measurable action. (Fig. 1) 


\section{Fig 1: The Basic Process of Affiliate Marketing}

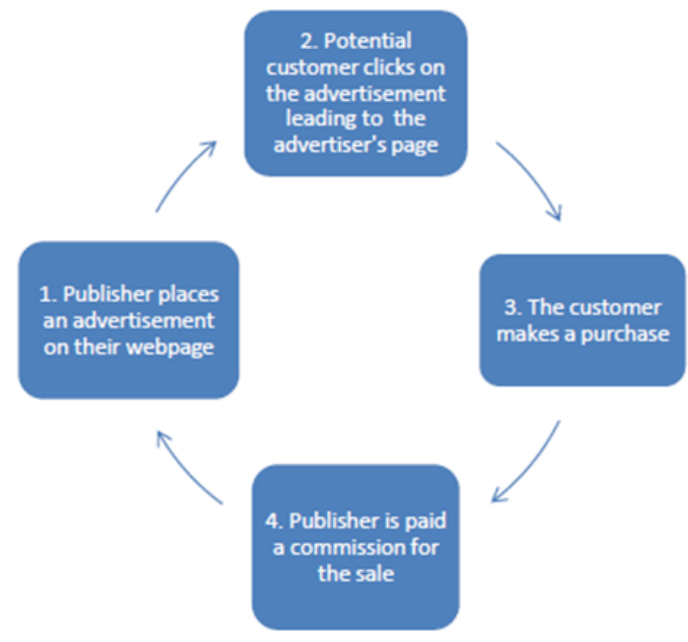

\section{TERMINOLOGY}

\subsection{Merchant}

The affiliate marketing merchant refers to a website looking for selling goods or services via online advertising. This is evident in online commerce from the web's largest sellers (e.g. Amazon) to mom-and-pop specialty sites.

\subsection{Affiliate}

The affiliate or publisher refers to a website that offers links to its visitors. For instance, along with posting a book to a blog or discussion forum, an affiliate may offer a link to Amazon to facilitate readers' purchase. In the same way, a travel guide site can provide link to a page at Trivago offering hotels in the area along with introducing a vacation destination. In the best scenario, the affiliate's links add to usefulness of the content along with paying the publisher. (Fig. 2)

Fig 2: The Sample of Affiliate Company

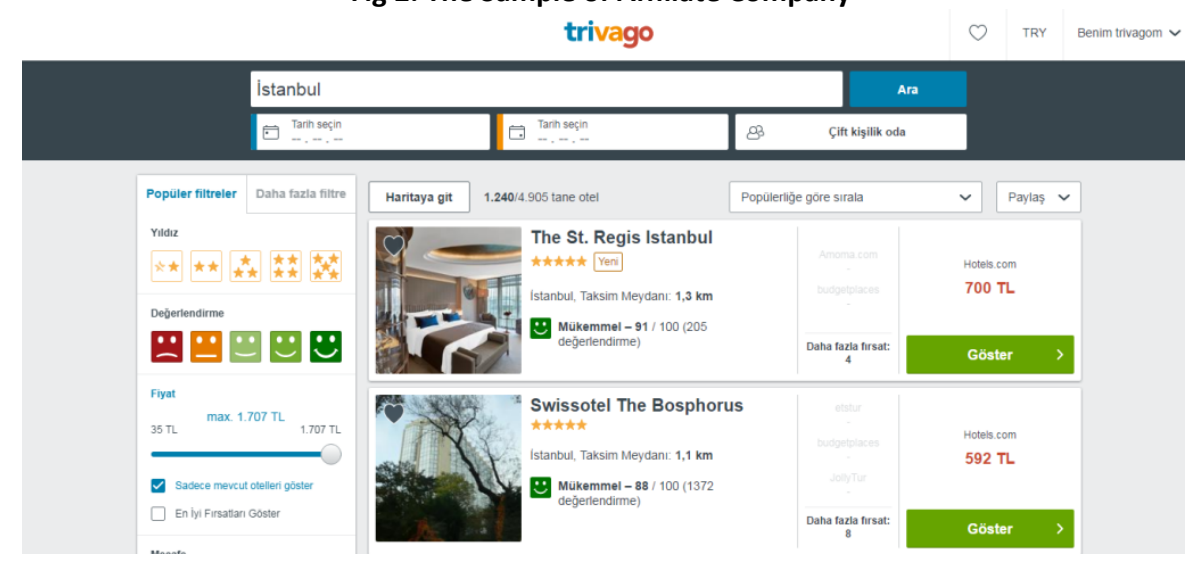

\subsection{Network}

The network provides connection between merchants and affiliates. Many merchants trust on networks for tracking, administration, and accounting purposes. This is needed to log which users clicked on what link and made what purchase, and consequently, develop a secure website for affiliates to obtain links and examine the results. The networks also offer effective consolidated payments to several affiliates on monthly bases.

However, many merchants have more tendency to the benefits of specialization. Networks introduce rules on permissible affiliate practices. By becoming a member of a network, the merchant can breach many of these rules or introduce other requirements of its own. 
affiliate program: The rules of an affiliate program (e.g. how much affiliates will be paid, permitted behaviors, participation criteria for the affiliates) are set by the affiliate program managers.

Affiliate marketing as transaction oriented, which caused no liability for joint future success or exclusivity restrictions. Affiliate programs need little effort and investment, which makes it also easy to terminate.

Currently, the number of companies that have initiated their own affiliate programs to reach new customers is growing. Affiliate networks have emerged in the form of intermediaries between content providers and merchants and provide solutions to handle affiliate programs.

Although, it is possible for the companies to select a few content providers and provide an opportunity for participation in an affiliate program, in practice it is the content providers who make decision about the ad content suitable for their websites. Given the increasing number of affiliate programs found on the internet, content providers can choose from a large diversity.

Figure 3:Role and Responsibilities in Affiliate Marketing

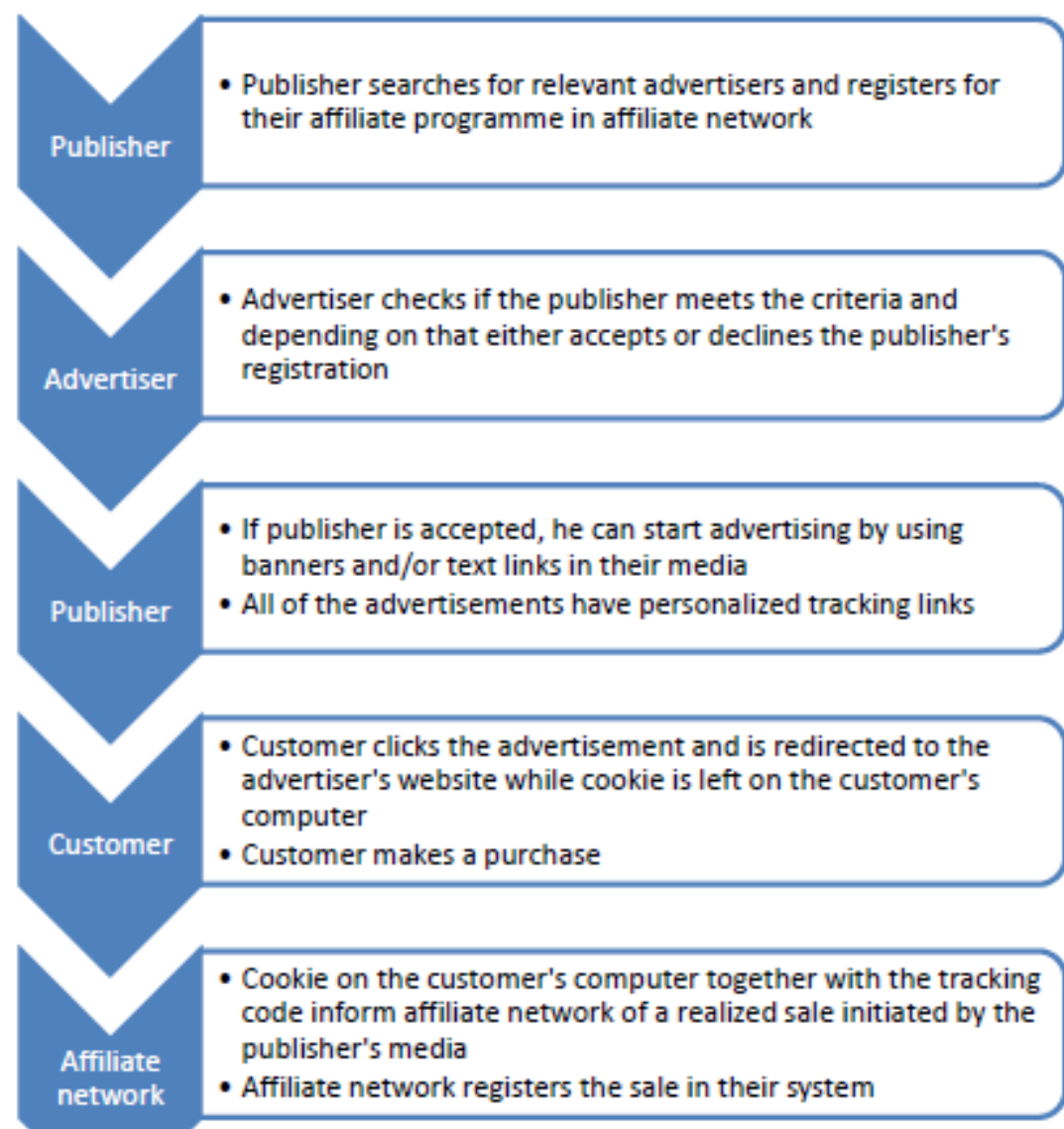

- Advertiser has to accept or decline the sale in the affiliate
network system
- Such things as a possible return of the product by the customer
needs to be considered in this phase


Affiliate networks provide affiliate programs to websites so that instead of running an affiliate program, the seller can use the affiliate network. The network provides services such as tracking publisher's sales, pay out the commissions and provide consultancy service to advertisers and publishers should a problem or question is raised. It also charges advertisers based on the results. Moreover, affiliate network determines minimum transaction revenue for the advertiser.

By clicking on an affiliate link or banner, the customer allows cookies being saved in their computer. The information of the cookie is sent to the affiliate network along with details such as the timestamp and technical details of the customer's browser and computer. The cookies stay in the customer's computer for 30 days, in general. If a purchase is made during these 30 days, the publisher will receive a commission for the sale. Therefore, it is not necessary to make a purchaser immediately of the clink. After completion of the purchase the final "thanks for the purchase" page send the order number, time stamp, and publisher identification number so that the affiliate network can track the sale.

\section{TYPES OF AFFILIATE MARKETING}

By definition, affiliate marketing is defined as an agreement achieved between a merchant and content providers for promoting merchant's products/services at their websites. Based on the agreement, the content provider is paid when the visitors from their website perform a specific action.

Therefore, in an affiliate marketing arrangement, in addition to delivering the advertisement, the content provider needs to persuade users to become customers. Thus, affiliate marketing is also called performance marketing.

There are two categories of affiliate marketing; one-to-one affiliate marketing and one-to-many affiliate marketing. In the former, the merchant signs a contract with a selected affiliate, in which the terms are negotiable without influencing contracts with other affiliates. This form of affiliate arrangement is usually adopted by major players at the market who has the capacity to lure many potential customers to the merchant's website.

By using one-to-many affiliate programs, the merchant offers identical condition for all affiliates and they are free to join the program. This forms of arrangement is used when the merchant cooperates with several affiliates and negotiating contract terms with all providers is too costly. Also affiliate marketing is specifically beneficial to small websites as without such arrangements, they do not have the opportunity of selling to major advertisers. Thus, these websites can enjoy great advantages from affiliate networks.

Companies can either develop a private affiliate program at their website or join third-party networks and take advantage of their technological solutions. According Marketing Terms (2007), affiliate network is "a value-added intermediary providing services, including aggregation, for affiliate merchants and affiliates."

\section{STANDARDIZATION IN AFFILIATE MARKETING}

Affiliate marketing enables notable performance incentives with wider efficiencies of online advertising.

The rule of affiliate marketing payments are aimed at protecting advertisers against wasted expenses. In this regard, the payment structures and the consequential risks of other online ads systems are notable. For instance, a reasonable concern of the advertiser might be that few users would click on its buying display ads; this might be due to irrelevance of the ads to the users' interests or poor placement of the ads. The advertiser does not have control over all these factors: standard contracts enable the advertising networks determine the sites that will display a specific ad.

For example one of the top affiliate networks, LinkShare, promised the advertisers that they are required to make payment to an affiliate only when a sale or other specific action is performed by the user. LinkShare believes that this method is highly efficient. Following the same path, Commission Junction affiliate network states that only when a determined action is taken by the user, the advertiser will be charged.

It is true that practitioners believe that affiliate marketing is structurally free of fraud, in practice however, there are significant risks to be concerned about that will be explain in next section.

\section{ADVANTAGE OF AFFILIATE MARKETING}

Although, there are theoretical definition for the advantages of affiliate marketing for merchants, there is no proper description of the benefits for content providers. Content providers face the risk pertinent with using affiliate marketing. Still, there is no clear answer for the question why and when they decide to take the risk and not using other types of online advertising.

To make sure that affiliate programs achieve the expected results, companies and content providers need to establish a win-win relationship that may result in generating adequate sale at the websites of the merchants and sufficient earning for the content providers. The determining an attractive commission rate and commission model are essential to lure content providers to an affiliate program. 
Advantages of affiliate marketing can be examined from two different perspectives; i) merchants who use affiliate marketing as a part of their marketing strategy, and ii) the content providers - affiliates, who display products/services of merchants on their websites Affiliate marketing provides opportunities of revenues from the website for the content providers; in addition, they can enjoy the opportunity to cooperate with a large number of merchants, which is not possible otherwise.

Participation in the affiliate program is most beneficial for the content providers when there is a strong connection between the website products/services promoted through the program. The connection is rooted in the product type, perception of brand, customer loyalty, and the like.

In addition to the information noted above, affiliate marketing provides a capacity to monitor activity of the customers after they click on the ads. This is done using a cookie that is stored on the potential customer's computer . Merchants are able to track the customers' activity for several days and weeks and if a sale is performed in this period, the content provider receives the commission.

\section{DISADVANTAGE OF AFFILIATE MARKETING}

There are some disadvantages cases by using affiliate marketing network that we discuss in this part of paper.

\subsection{Fraud in Affiliate Marketing}

Our representation of affiliate litigation (Edelman, 2012) highlights many disputes that are important enough to lead to a legal action. Since the methods under consideration are featured with the elements of common law fraud and they are considered as fraud in both civil and criminal litigation, they are known as affiliate fraud. Commission, in many affiliate marketing schedules, is payable only when a user performs a purchase. Thereby, to charge a merchant, the affiliate must make the merchant's record show that the affiliate has actually caused extra sale. In fact, an affiliate might penetrate server of the merchant to change the records directly. However, an attacker with privileged access to merchants' servers does not need to stop at affiliate fraud. In practice, affiliate fraud is mainly about focusing on the schemes to spot the users who had already made a purchase decision.

\subsection{Fraud Categories}

1. Adware: The user visits web page of a merchant using a computer that runs a specific advertising software; the software monitors the user's activity and takes the user to the affiliate's marketing link. If then the user performs the purchase, the affiliate will be paid as the assumed cause of the purchase.

2. Cookie-stuffing: the user visits a web page of which a section can claim to refer the user to a merchant. When the user makes a purchase from the merchant within the preset time period (usually seven to 30 days) the affiliate will receive a commission. In another scenario, the affiliate may design its cookie-stuffing as a component of other web pages.

3. Typosquatting: Affiliates are in charge of registering domain names that are misspelling of merchant's domain names. If a user misspells a merchant's domain name in a predictable way for the affiliate, the user is redirected to the affiliate's site. Then the user is taken to an affiliate link and then to the merchant. Afterward, the affiliate will received the commission when the user makes a payment.

4. Loyalty software: by installing a loyalty software on a user's computer, affiliates ensure that the user is well informed about probable rebates, points, or other advantages of purchasing from specific merchants. The software leads the user via an affiliate's link when the user want to go directly to a merchant's website.

\section{RELATIONSHIP BETWEEN ONLINE ADVERTISING AND AFFILATE MARKETING}

The figure 4 illustrates the different forms of online advertising available to the merchants to acquire customers. The highlighted fields enjoy advantage of a network of content providers, while the dark green fields indicate the areas that 
affiliate marketing is an option. As noted below, it is possible to use affiliate marketing in e-mail advertising through adding links with affiliate reference to the text of e-mail or newsletter. In the case of web-based advertising, affiliate links are connected to banners, textlinks, advertorials and interstitials. Sponsorship and microsites are not recommended as the visitors stay in the website of the content providers so that payment models cannot be used. Affiliate marketing can be used in search engine marketing; a topic that we will return to it later.

Figure 4: Overview of online advertising and its relationship to affiliate marketing

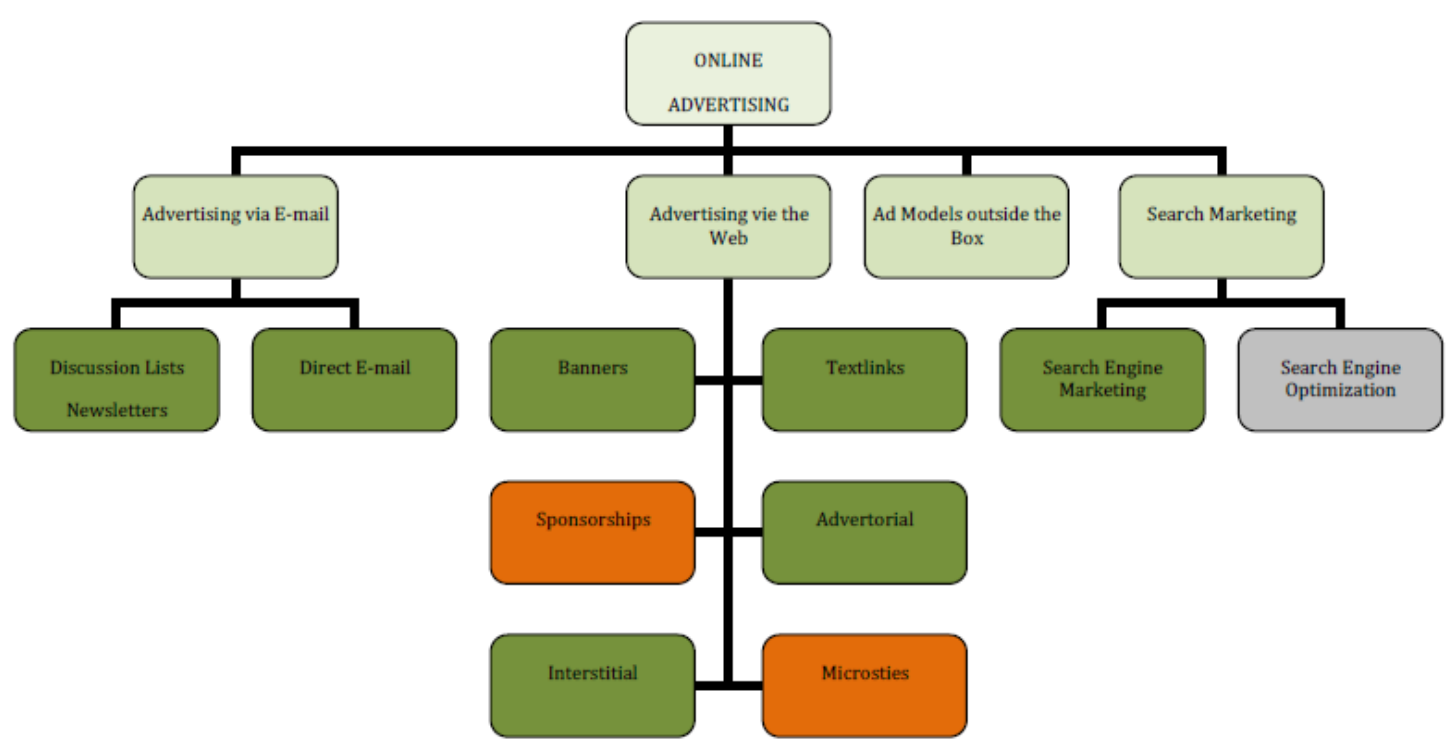

the some cases of using affiliate marketing are storefronts, so that content providers can market products/services of other companies at their own branded website using technological solutions offered to them by the advertiser. There is no need for the website visitors to leave the content providers' website to complete the purchase. Storefronts are usually called "white lables."

\section{COMPENSATION MODELS IN AFFILATE MARKETING}

As highlighted by Fiore and in affiliate marketing in particular, advertisers can choose one of the three compensation models explained above to determine commissions payable to the content providers.

- $\quad$ Pay per sale (PPS): commission is paid for each sale by the visitor from the affiliate website.

- $\quad$ Pay per lead (PPL): commission is paid to the affiliate when one of its visitors performs a specific action (e.g. subscribing a newsletter, filling out a questionnaire). Note: another term of PPL is pay per action (PPA)

- $\quad$ Pay per click (PPC): commission is paid to the content provider for each click at the link to the advertiser's website. (Fiore, 2001; 125)

\subsection{CPS (Cost-Per-Sale)}

The term CPS, also known as PPS (Pay Per Sale), refers to a low-risk, high-profit, revenue-sharing model utilized by marketers to attract new customers to their products or services. CPS pays a determined commission to the affiliate marketer who refers a lead that results in a purchase. CPS model is more preferred by the marketers as they are only required to pay a commission when they sell to a customer. In fact, it is a free marketing and advertising scheme where the affiliate produces the lead without receiving a upfront cost. 


\subsection{CPA (Cost-Per-Action)}

Affiliate marketing is an easy way to address banner blindness, since content providers have the deepest insight into their customers and know what advertisings is more effective. Additionally, the content provider has all the reason to avoid banner blindness, since affiliate marketing campaigns are paid per action (PPA).

Under CPA setting, the affiliates receive a fee when a specific action is perform by the referral or lead. Among such actions are clicks, impressions, form submits, sign-ups, registrations, or opt-ins. Because CPS are not necessarily featured with a direct sale and more risk taking, the payout percentages are smaller than those in CPS setting.

Three basic plans introduced above might be mixed with other types. The most common combinations are two-tier and residual programs. The former functions based on multilevel marketing and the affiliates are paid in return of the actions taken by the newly recruited affiliates. In the latter, a commission is paid for all the purchases performed by previously referred visitors during a specific time period.

The commission paid by the merchants might be based on a flat fee (i.e. the affiliate receive a specific amount of money for every sale) or based on a percentage of sale value.

\subsection{Business models of Content Providers}

To have a better insight into the ways that content providers place themselves in the online value chain and earn money from their websites, one needs to learn about their sources of revenue. Evaluating the condition in which different forms of online advertising are efficient or not needs insight into the available business models.

There are seven sources of income for online content providers:

1. Online advertising

2. Subscription fee for online content

3. Online ordering of print publication

4. Syndication/revenue sharing with online services

5. Per-unit charges for online content

6. Online sale of non-content merchandise and services

7. Affiliate marketing

However, the mentioned article only focused on magazine and newspaper companies so that some of the mentioned sources are not available in general. Strauss et al. proposed a better model in which business models for cybermediaries are categorized as follows:

- Brokerage model

- $\quad$ Agent model

- Online retailing

\section{Brokerage model}

In this model, the cybermediary functions as a supplier of negotiations platform between buyers and sellers. The cybermediary might charge the buyer, the seller, or the both. These companies function on the basis of business to business (B2B), business to customer (B2C) or customer to customer (C2C) models. In general, they offer several value added services for both buyers and sellers. There are two common models in brokerage model: 
- Online exchange

- Online auction

\section{Agent model}

As explained by Strauss, online agents act as representative and in interest of the buyer or seller. Following structures are notable in the agent model:

- Models representing sellers
○ Selling agent
- Metamediaries
- Virtual malls

- Models representing buyers
○ Purchasing agents
- Reverse auction
- Buyer cooperative

\section{Selling Agents}

Strauss illustrated selling agents as cypermediaries that act as representative of one or several companies and offer them services to promote their sale. In this arrangement, a commission model is used within an affiliate program. The agent receives a commission when it refers a user that will perform a purchase or other specification actions. While an agent in traditional marketing represents one producers, in online environment, an agent can represent an industry and recommend rival products.

This model is generally used in travel industry and the agents usually represent airlines, hotels, car rental companies and the like. From the customer's viewpoint, the agent provide valuable services as, through their services, they can find better deals and enjoy more convenient buying process.

Another notable model is catalog aggregators, in which information about products is collected in online catalogs and customers can choose among several products. The customer is also provided with real time prices and products information. This model is more general in B2B Solutions. At the most advanced level, catalog aggregators might provide direct link to venders' ERP (enterprise resource planning) systems.

\section{Metamediaries}

As explained by Strauss, the term "metamediary" refers to a website that creates connection between stakeholders and an important event like purchase of asset or marriage. Metamediaries shorten the customer's search for information, guarantee quality of suppliers, and supply pertinent information. They also act as facilitators of transactions. On the other hand, merchants enjoy the traffic to their website provided by metamediaries and co-branding. Metamediaries work based on commission models. Strauss et al. noted that what matters between the metamediary and customers is the trust and to preserve their unbiased image, some of them do not even utilize web ads.

\section{Virtual malls}

Virtual malls function like brick-and-mortar shopping malls. Like the metamediaries model, stores enjoy benefits of virtual mall traffic and co-branding. Customers, on the other hand, enjoy the benefits of having one shopping cart in all stores and do purchase while benefiting loyalty programs, gift registries, search facilities and shopping suggestions, recommendations, and product reviews. 


\section{Purchasing agents}

A purchasing agent collects orders of individual customers who can remain anonymous, and perform large volume order for better price. Practically, the customer is in the position to determine the price of their preference.

\section{Reserve auction}

Reserve auction works alike purchasing agents in all aspects with the exception that the business keeps its separate identity. The customer can determine their preferred price and the vendors bid to reach the price or offer a lowest price to grab attention of the buyer.

\section{Buyer cooperative}

An alternation of purchasing agents is buyer cooperative, where, customers are grouped in order to achieve lower prices; however, in buyer cooperative, a relationship exists between the amount of buyers and the price. Buyers know the exact number of buyers they need to collect to reduce the price. In such a case, buyers are in charge of marketing and finding more buyers.

\section{Online retailing}

Online retailers means online stores, so that they buy goods from the suppliers and sell them to the customers.

\section{CONCLUSION}

It has been for decades or one as some say centuries that businesses have complained about effectiveness of advertisement activities. While the costs of advertisement needs to be paid beforehand and the expected benefits, if any, will come later, the advertisers are always at the risk of low performance or no-performance in their campaigns. In the face of this drawback, affiliate marketing brings in new changes; it introduces performance-based approach to online marketing and the advertisers are needed to pay only when a sale takes place. Thanks to the reliable online tacking that highlights the sales pertinent to affiliates, advertisers enjoy a notable decrease in their risk.

In this article affiliate marketing and all its features from theoretical aspect are discussed in this article, also commissioner and marketing plans in practice, the requirements, and the environment are discussed.

\section{REFERENCES}

Barbora benediktová , lukas nevosad (2008), Master Thesis, lulea teknik üniversitesi, ISSN: 1653-0187 , mart 2008 PP:30-55

Zeff, R. L., \& Aronson. (1999). Advertising on the Internet. 2nd ed. New York: Wiley Computer Publishing , ISBN 0-471-34404PP 230-301

Chaffey, D. (2003). Internet Marketing: Strategy, Implementation and Practice. 2nd ed. New York: Financial Times.

Chatterjee, D.D., Pacini, C., and Sambamurthy, V.(2002) "The Shareholder-Wealth and Trading-Volume Effects of Information Technology Infrastructure Investments," Journal of Management Information Systems (19:2), Fall 2002, pp 7-42.

Edelman, Benjamin (2013),The design of online advertising markets. In Nir Vulkan, Alvin Roth, and Zvika Neeman, editors, The Handbook of Market Design. Oxford University Press, 2013.

Stefan Schwarz (2011), Affiliate Marketing : A case study of Ticket Express GesmBHoticket.com , Master Thises, Modul Vienna University

Ben Edelmen ,Weley Brandly (2014) ,Risk Information and Incentives in Online Affiliate Marketing ,Working paper ,Harward Business School, haziran 2014

United States of America v. Hogan (2010), U.S. District Court for the Northern District of California, CR 10-0495-JF. Pp:6-7

Baker, George P. and Thomas Hubbard (2003), “Make Versus Buy in Trucking: Asset Ownership, Job Design, and Information," American Economic Review , 93 (3), 551-72.

Blake, Thomas, Chris Nosko, and Steven Tadelis (2013), “Consumer Heterogeneity and Paid Search Effectiveness: A Large Scale Field Experiment," mimeo, eBay Research Labs.

Lafontaine, Francine and Margaret Slade (2007), "Vertical Integration and Firm Boundaries: The Evidence," Journal of Economic Literature , 45 (September), 629-685.

Libai, Barak, Eyal Biyalogorsky, and Eitan Gerstner (2003), “Setting Referral Fees in Affiliate Marketing," Journal of Service Research , Vol 5 ,No 4 (May), 303-315. 
Moore, Tyler and Benjamin Edelman (2010), “Measuring the Perpetrators and Funders of Typosquatting," in Financial Cryptography Lecture Notes in Computer Science, Vol. 6052, RaduSion, ed. Berlin: Springer, 175-91.

Zhu, Yi and Kenneth Wilbur (2011), “Hybrid Advertising Auc-tions,"Marketing Science, 30 (2), PP .249-73.

Adamson, A.P. (2011). Brand Digital. Bratislava: Eastone Books. ISBN 978-80-8109- 192-6

Jurišová V. et al. (2012). Affiliate marketing. In Conference proceedings - International Scientific Conference New Trends in Marketing Social Responsibility. Trnava: FMK UCM. ISBN 978-80-8105- 438-9

Matúšová, J. (2013). Budovanie a komunikácia značky: Značka v PR a reklame. Trnava: FMK UCM. ISBN 978-80-8105-440-2

Murár, P. (2010). Sociálne médiá ako prostredie marketingovej komunikácie firmy. In Sborník příspěvků: III. mezinárodní vědecké konference doktorandů a mladých vědeckých pracovníků. Karviná: Slezká univerzita v Opavě, Obchodně podnikatelská fakulta v Karviné. ISBN 978-80-7248-620-5

Pizano, V. - Kusá, A. (2012). Typológia slovenských internetových používatel'ov podl'a vnímania nových foriem marketingovej komunikácie. Trnava: FMK UCM. ISBN 978-80-8105-425-9

D.M. Scott. (2010). Nové pravidlá marketingu a PR. Bratislava: Eastone Books. ISBN 978-80-8109-149-0

Dennis L. Duffy (2005), 'Affiliate Marketing and Its Impact on e-commerce', Journal of Consumer Marketing, vol. 22, no 3, pp.161 - 163.

Venu Gopal K., Saumendra das., Dr D.vishnu Murthy., (2012)., “EMAIL MARKETING: A PARADIGM SHIFT TO MARKETING” International Journal of Advanced Research in management and Social Sciences, Volume1, no1, July 2012, ISSN: 2278 -6236, pp.101-11 